\title{
Linjiang hongshui river super large bridge construction technology and health monitoring research
}

\author{
QIU Yi-mei ${ }^{1, a}$, CHEN Jun-xiang ${ }^{2, b}$ \\ ${ }^{1}$ Guangxi Vocational and Technical College of communications, Nanning 530023, China \\ ${ }^{2}$ Guangxi Transportation Research institute , Nanning 530007,China \\ agx5635604@sina.com, bjychxb@sina.com
}

Keywords: hongshui river; super large bridge; construction technique; health monitoring; research

Abstract: Combination of Linjiang hongshui river super major bridge engineering practice, the bridge span structure during the construction of CF60 of concrete raw materials and mix proportion, cantilever casting construction technology points and structural health monitoring, quantitative engineering health indicators, evaluation of concrete structures in a variety of adverse health conditions. Put forward the construction quality control measures and the defect control strategy, for the same kind of bridge construction reference.

\section{Preface}

Linjiang hongshui river super large bridge is the world bank loan project of Guangxi Hechi (Shuiren) to Nanning highway projects in ten key projects. For the prestressed concrete continuous rigid frame bridge $(75+125+75) \mathrm{m}$, the bridge length $275 \mathrm{~m}$, using two separate structure, single box single room box girder, setting longitudinal, transverse and vertical to the prestressing system. Construction of box girder using subsection cantilever symmetrical pouring method. The natural condition of bridge is complex, the river bed is $\mathrm{V}$ shaped section, the rainy season is long, the rainfall is big, the difficulty of construction is obviously increased. This paper focuses on the key technologies of health monitoring and defect, the construction process of Linjiang hongshui river bridge in the control strategy.

\section{Concrete raw materials and mix ratio}

Design requirements of box girder using CF60 self compacting high performance concrete, initial slump of $180 \sim 220 \mathrm{~mm}$, into the pump slump is $160 \mathrm{~mm}$, the initial setting time is not shorter than $12 \mathrm{~h}$.

\section{Concrete raw materials}

Cement. Guangxi Hua Hong cement Limited by Share Ltd P. II 52.5 Portland cement, the technical indicators are in line with the requirements of the inspection.

Fine aggregate. the second zone in the sand, fineness modulus of 2.6 2.9, the inspection of the technical indicators qualified.

Coarse aggregate. the particle size of $5 \sim 15 \mathrm{~mm}, 15 \sim 25 \mathrm{~mm}$ of mixed with crushed stone, according to 2:3 preparation, the inspection of the technical indicators of qualified.

Water. drinking water.

Fly ash. Grade I fly ash of Guangxi guest power plant, the technical indexes of the test are qualified.

Additive. Zhanjiang FDN high efficiency composite water reducing agent, the test of the technical indicators of qualified.

Steel fiber. Yueyang Huaxing steel fiber limited liability company.

Polyacrylonitrile fiber. Taian Zhiyong Engineering Materials Co., ltd. 


\section{Concrete mixture ratio}

According to the basic principles and engineering requirements of the CF60 high performance concrete mix ratio design, Under the standard conditions, the reasonable choice of water cement ratio, unit water consumption and sand ratio and so on are the main parameters, through the comparison test, determine the unit dosage of various kinds of materials which can meet the design strength, working performance, mechanical property, long term performance and durability, get optimal design mixture ratio. After field verification test, the performance of concrete mixture is stable, and the test results have good reproducibility, as shown in table 1.

Table 1. Concrete mix ratio recommendations and validation of test results

\begin{tabular}{|c|c|c|c|c|c|c|c|c|}
\hline Material name & cement & $\begin{array}{c}\text { Fine } \\
\text { aggregate }\end{array}$ & $\begin{array}{c}\text { Coarse } \\
\text { aggregate }\end{array}$ & Water & Fly ash & admixture & Steel iber & Polyacrylonitrile \\
\hline $\begin{array}{c}\text { Unit dosage } \\
\left(\mathrm{kg} / \mathrm{m}^{3}\right)\end{array}$ & 450 & 634 & 1034 & 155 & 79 & 7.935 & 79 & 0.794 \\
\hline Unit ratio & 1.000 & 1.409 & 2.298 & 0.344 & 0.178 & 0.018 & 0.178 & 0.002 \\
\hline $\begin{array}{c}\text { Trial mix amount } \\
(40 \mathrm{~L})\end{array}$ & 18.00 & 25.36 & 41.36 & 6.20 & 3.16 & 0.317 & 3.16 & 0.032 \\
\hline $\begin{array}{c}\text { Mixture density } \\
\left(\mathrm{kg} / \mathrm{m}^{3}\right)\end{array}$ & 2440 & \multicolumn{2}{|c|}{ Initial setting time (h) } & 14 & \multirow{2}{*}{\multicolumn{2}{|c|}{$\begin{array}{c}\text { Actual measurement } \\
\text { compressive strength } \\
(\mathrm{MPa})\end{array}$}} & $7 \mathrm{~d}$ & 62.8 \\
\hline $\begin{array}{c}\text { Slump } \\
(\mathrm{mm})\end{array}$ & 190 & \multicolumn{2}{|c|}{ Final setting time (h) } & 17 & & & $28 \mathrm{~d}$ & 71.5 \\
\hline
\end{tabular}

\section{Box girder casting construction technique}

\section{Construction methods}

Linjiang hongshui river super large bridge construction technology and health monitoring research super large bridge is a prestressed concrete continuous rigid frame bridge , the cantilever casting construction of the box girder, the cantilever casting is divided into $21 \times 4=84$ blocks, each of which is constructed by 2 symmetrical and parallel operation of hanging baskets. Each hanging basket main truss is composed of 4 truss plates, and the load capacity of a single hanging basket is not less than 650 tons, its own weight is about 200 tons (including the template).

\section{Box girder concrete casting}

\section{0\# block construction points}

According to the structural characteristics of the project and the actual situation of the site, 0\# intends to use the bracket method for construction. 0\# block location pipeline intensive, embedded parts and preformed hole many, structure and stress situation is complex. Its construction process is: Bracket construction $\rightarrow$ Bottom mold installation $\rightarrow$ Outside mold installation $\rightarrow$ Web plate and lateral isolation plate vertical prestressed reinforcement Installation and fixation $\rightarrow$ Bottom plate, web plate, and lateral isolation plate a steel bar banding lashing $\rightarrow$ Web plate corrugated pipe installation and positioning $\rightarrow$ Install internal model $\rightarrow$ Top plate of rebar lashing $\rightarrow$ Top plate corrugated pipe installation and positioning $\rightarrow$ Install the horn mouth ( anchor plate) $\rightarrow$ Embedded parts installation $\rightarrow$ Installation and debugging perfusion system $\rightarrow$ Pouring concrete $\rightarrow$ Curing $\rightarrow$ Keeping in good health $\rightarrow$ Compacted pulp $\rightarrow$ Open the template.

\section{Cantilever construction technology}

The hanging basket is tested by preloading, and after obtaining the relevant control parameters, the cantilever casting construction of the box beam can be started, the main construction process is:

The hanging basket is installed in place, and the bottom template is adjusted to the construction control elevation. Adjust side template to the construction control elevation, and fix it. 
Lashing box girder base plate, the web plate steel bar, Installation and positioning of Web prestressed beam pipe and the vertical prestressed reinforcement, with ducts and embedded parts installation.

Internal model in place, adjust the top elevation and fixed.

Lashing of box girder roof, a wing plate reinforced installation, positioning of prestressed roof beam pipes and transverse prestressed beam and anchor plate, reserved channel and embedded parts installation construction.

Cast concrete, pouring sequence: Bottom plate, web plate, top plate. Casting to achieve uniform, vibrating compaction, to ensure the quality of internal and external.

Concrete curing, to ensure the curing conditions and time, during the period of prestressed pipe cleaning, pre stressed steel beam and end concrete chisel hair.

When the tensile strength of concrete is reached, the tension and pipeline pressure grouting.

The hanging basket unloaded, demoulding, moved forward in place, on to the next segment construction.

\section{Closure section key points of construction}

The entire bridge has 3 closure sections, long $2 \mathrm{~m}$. The closure section plan use hanging rack to construction, when the hanging basket construction to closure section, the hanging basket bottom platform is converted to the already pouring box girder and anchoring, is used as the support of the closure sections construction. Before the construction of closure sections, should according to the design of the stiff skeleton lock on the beam, the stiff skeleton design must meet the specifications and design requirements. The closure section construction site is pouring process: Choose the best closure temperature $\left(20 \pm 2^{\circ} \mathrm{C}\right)$ lock two cantilever end $\rightarrow$ Install template $\rightarrow$ The installation of prestressed beam closure $\rightarrow$ Pouring concrete of the closure section $\rightarrow$ Curing $\rightarrow$ Tension prestress $\rightarrow$ Grouting seal $\rightarrow$ Removal of the template hanger.

\section{Prestress construction}

\section{Prestress intelligence tension}

Box girder prestressed tension must wait until the concrete strength to be reached design strength and age not less than 14 days. Using intelligent tension tensioning system, mainly composed of system control platform, intelligent instrument, intelligent lifting jack, system can precise control of prestressing force value, the error range is less than $\pm 1 \%$. Real-time acquisition of steel strand elongation, elongation should be controlled in the range of $\pm 6 \%$, to achieve the stress and elongation synchronization "double control". A computer control two or more lifting jack at the same time, synchronous symmetrical tension, to achieve a "multi top synchronous tension" process.

\section{Prestressed pore intelligence pressure grouting}

Beam duct grouting pressure slurry system with intelligence, system will speed pulping machine, slurry storage tank, slurry instrument, slurry return measurement and control instrument, pressure pump integrated into a whole, the field use only need to be put into the pulp pipe, the return pipe and the prestressed pipe butt joint, can immediately carry out the pressure grouting construction.Pore pressure grouting, to accurately control the pressure, adjust the flow rate; accurately control the water to cement ratio, to ensure the cementation effect; slurry filled pipeline continuous circulation to exclude the air in the pipeline.

\section{Bridge span structure health monitoring}

Bridge span concrete structure health monitoring, to quantify the main factors impact on the quality of concrete, health status evaluation, formulate reasonable treatment scheme. 


\section{Structural health monitoring}

\section{Concrete hydration heat temperature test}

Measuring point position. Center of box girder web thickness.

Test method. starting from the concrete into the mold, measuring hydration heat temperature changes with time, the internal temperature through the pre embedded sensors using special SZZX-ZH digital display instrument to test, surface and atmospheric temperature using temperature observation of test instrument.

Test results. As shown in table 2 and figure 1.

Thus it can be seen, the center temperature of the box girder web plate has experienced the temperature rise stage and the temperature drop stage with the age of concrete, and has the typical characteristics of general concrete hydration heat temperature change; surface temperature of the web plate is influenced by the sunshine, and changes with the temperature of the sunshine.

Table2.The test record of hydration heat temperature of concrete

\begin{tabular}{|c|c|c|c|c|}
\hline $\begin{array}{l}\text { Observation } \\
\text { time } \\
(\mathrm{h})\end{array}$ & $\begin{array}{c}\text { Plate thickness center } \\
\text { temperature } \\
\left({ }^{\circ} \mathrm{C}\right)\end{array}$ & $\begin{array}{c}\text { Concrete surface } \\
\text { temperature } \\
\left({ }^{\circ} \mathrm{C}\right)\end{array}$ & $\begin{array}{c}\text { Sunshine } \\
\text { temperature } \\
\left({ }^{\circ} \mathrm{C}\right)\end{array}$ & $\begin{array}{c}\text { Web plate temperature difference } \\
\text { between internal and external } \\
\left({ }^{\circ} \mathrm{C}\right)\end{array}$ \\
\hline 1 & 32 & 32 & 24 & 0 \\
\hline 2 & 33 & 32 & 21 & 1 \\
\hline 4 & 34 & 32 & 15.5 & 2 \\
\hline 8 & 41 & 32.5 & 14 & 8.5 \\
\hline 12 & 60.5 & 33 & 21 & 27.5 \\
\hline 16 & 72 & 43.5 & 33 & 28.5 \\
\hline 20 & 73 & 39 & 28 & 34 \\
\hline 24 & 70.5 & 31.5 & 22 & 39 \\
\hline 28 & 67 & 28.5 & 22 & 38.5 \\
\hline 32 & 63 & 27 & 21 & 35 \\
\hline 36 & 59 & 25 & 25 & 33 \\
\hline 40 & 55 & 27 & 31 & 28 \\
\hline 44 & 50 & 35 & 27 & 15 \\
\hline 48 & 48.5 & 27.5 & 20 & 21 \\
\hline
\end{tabular}

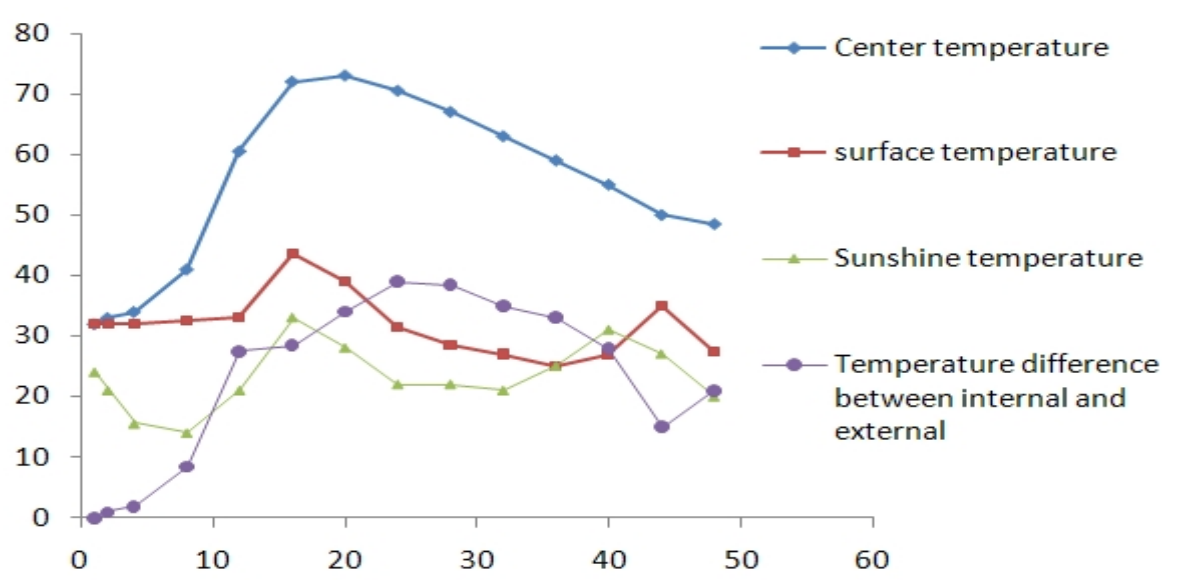

Figure 1. Variation of temperature with age of concrete

\section{Testing of strength and carbonation depth of concrete}

Using the digital rebound instrument to determination of the strength of structural concrete, evaluation of the uniformity of structural concrete. The rebound value of the bridge span structure 
concrete strength was measured according to the standard age, and the 28 day compressive strength of the conversion was more than 60MPa, and in accordance with the growth of the age and increase the law of change. At the same time, the value of carbonation depth of concrete surface is measured, and the measured value is less than $0.5 \mathrm{~mm}$.

\section{Structural stress and strain detection}

Through SZX-ZH digital display instrument simultaneous determination of the bridge span concrete structure strain at various states, the position of the sensor are located in the 1,2 beam segment joints left and right of the upper and lower edges, were measured 3 to 21 block the initial value of the strain, initial stress value (MPA), before and after pouring the strain difference, tension before and after pouring the strain difference, before and after pouring the stress difference, tension before and after the stress difference, the stage of cumulative stress and total accumulated stress, to obtain concrete beam structure in weight under the condition of internal strain development trend, the strain state of the evaluation of internal box girder, verification concrete structure thermal expansion and contraction of the regularity.

\section{Structural crack detection}

After the crack of bridge span structure appear, regular inspection and observation. According to the characteristic and position of the crack, the design and construction data are analyzed to find out the nature, cause and harm degree of the fracture. Measure the length of concrete structure crack, width and depth of the cracks in the concrete structure, evaluate the degree of cracking, quantify crack trend with the age of the determined crack is in need of repair, and provides a reliable basis for the establishment of crack prevention and treatment programs. The specific test results are shown in table 3.

Table 3. Crack detection results of concrete structures

\begin{tabular}{|c|c|c|c|c|c|c|c|c|c|}
\hline $\begin{array}{c}\text { Pier serial } \\
\text { number }\end{array}$ & $\begin{array}{l}\text { North and } \\
\text { south } \\
\text { direction }\end{array}$ & $\begin{array}{c}\text { Block } \\
\text { number }\end{array}$ & $\begin{array}{l}\text { Crack } \\
\text { number }\end{array}$ & $\begin{array}{l}\text { Molding } \\
\text { date }\end{array}$ & Test date & $\begin{array}{l}\text { Age } \\
\text { (day) }\end{array}$ & $\begin{array}{l}\text { Depth } \\
(\mathrm{mm})\end{array}$ & $\begin{array}{l}\text { Width } \\
(\mathrm{mm})\end{array}$ & $\begin{array}{c}\text { Length } \\
(\mathrm{cm})\end{array}$ \\
\hline \multirow{3}{*}{ No.1 pier } & \multirow{3}{*}{$\begin{array}{c}\text { South } \\
\text { web plate }\end{array}$} & \multirow{3}{*}{6} & \multirow{3}{*}{4} & \multirow{3}{*}{ 2007.12.07 } & 2007.12 .14 & 7 & 30 & 0.20 & \multirow{3}{*}{123} \\
\hline & & & & & 2008.01 .12 & 28 & 25 & 0.16 & \\
\hline & & & & & 2008.03 .01 & 90 & 19 & 0.1 & \\
\hline \multirow{3}{*}{ No.1 pier } & \multirow{3}{*}{$\begin{array}{c}\text { North } \\
\text { web plate }\end{array}$} & \multirow{3}{*}{2} & \multirow{3}{*}{3} & \multirow{3}{*}{2007.10 .15} & 2007.10 .22 & 7 & 31 & 0.14 & \multirow{3}{*}{162} \\
\hline & & & & & 2007.11 .19 & 28 & 33 & 0.16 & \\
\hline & & & & & 2008.01 .20 & 90 & 36 & 0.20 & \\
\hline \multirow{3}{*}{ No.2 pier } & \multirow{3}{*}{$\begin{array}{c}\text { South } \\
\text { web plate }\end{array}$} & \multirow{3}{*}{2} & \multirow{3}{*}{2} & \multirow{3}{*}{ 2007.10.11 } & 2007.10 .18 & 7 & 25 & 0.10 & \multirow{3}{*}{113} \\
\hline & & & & & 2007.11 .15 & 28 & 10 & 0.08 & \\
\hline & & & & & 2008.01 .16 & 90 & 8 & 0.05 & \\
\hline \multirow{3}{*}{ No.2 pier } & \multirow{3}{*}{$\begin{array}{c}\text { North } \\
\text { web plate }\end{array}$} & \multirow{3}{*}{2} & \multirow{3}{*}{1} & \multirow{3}{*}{ 2007.10.11 } & 2007.10 .18 & 7 & 39 & 0.22 & \multirow{3}{*}{75} \\
\hline & & & & & 2007.11 .15 & 28 & 34 & 0.20 & \\
\hline & & & & & 2008.01 .16 & 90 & 28 & 0.13 & \\
\hline
\end{tabular}

The measured data show that the width and depth of the crack are decreased with the increase of the age, in the age of more than 90 days, most of the crack width is basically in line with the provisions of the scope. Obviously, most cracks have certain self-healing ability or calcium carbide filled or caused by prestressing force. Bridge span structure box girder cracks, the most direct reason is the climatic conditions, early maintenance and human factors, etc.

\section{Structural health strategy}

The construction quality and health condition of the bridge concrete structure are mainly determined by the construction process quality control and structure maintenance strategy. Structural defect control strategy is as follows:

Construction control. Standard construction operation, ensure the construction quality of concrete, improve the ability of concrete structure to resist the damage of environmental factors.

Temperature control. Temperature control index of concrete pouring and curing process: Into the mold temperature, the temperature should not be higher than $30{ }^{\circ} \mathrm{C}$, preferably below $25^{\circ} \mathrm{C}$; The 
highest temperature, the maximum temperature of the concrete into the mold is generally not higher than $65{ }^{\circ} \mathrm{C}$, the best control in the following $60^{\circ} \mathrm{C}$; The maximum temperature difference, the highest temperature and the difference of the surface temperature in any section of the member at any section is not higher than $20^{\circ} \mathrm{C}$; Cooling rate, the cooling rate of the concrete surface of the bridge engineering should be controlled at $3{ }^{\circ} \mathrm{C} / \mathrm{h}$. Corresponding temperature control measures: select the appropriate pouring time; uninterruptible cooling templates before pouring and casting process.

Maintenance strateg. Mainly to control temperature and humidity, should be used as far as possible water storage or sprinkler curing; Spray curing is best used in the temperature rising stage to avoid the sudden change of the surface temperature of concrete.

\section{Conclusion}

Linjiang hongshui river continuous rigid frame bridge, complex loading, impact factors and varied. The durability of concrete structure to a large extent also depends on the level of construction technology, construction quality control of concrete error, structure construction, temperature control and curing conditions, etc. To build durable concrete structures in a certain environment, guarantee the use performance and service life of engineering structure, construction technology and quality control must be strictly process, tracking quantitative health indicators and evaluation of health, scientific construction technology solutions and maintenance strategy.

\section{References}

[1] JTG/T F50-2011, technical specifications for construction of highway bridges and culverts [S].

[2] JTG F80/1-2004, "highway engineering quality inspection and evaluation standard" [S].

[3] GB175-2007, "General Portland cement" [S].

[4] QIU Yi-mei, XIN Zi-yang, ZENG Zong-wen. Long span continuous box girder concrete structure durability of research [J], "concrete", 4 (2009) .

[5] QIU Yi-mei, CHEN Xiao-bing. Application and popularization of highway steel fiber concrete pavement [J], "highway traffic science and technol ogy", 3(2011) . 